\title{
Success Dimensions for Major Real Estate Projects: The Case of Stadium Development
}

\author{
Torben Bernhold ${ }^{1}$, Frank Lattuch ${ }^{2}$, Frank Riemenschneider ${ }^{3}$ \\ ${ }^{1,3}$ Muenster University of Applied Sciences, ${ }^{2} K P M G$ AG
}

\begin{abstract}
Although many stadiums in the top European football leagues have been constructed recently, a majority of European stadiums were built more than 35 years ago. New requirements and increased expectations by different stakeholder groups lead to complex challenges that stadium development teams face today. With a constructivist understanding of success, this article highlights critical success dimensions for stadium development projects such as (a) vision and expectation, (b) risk and feasibility, (c) project planning and design, (d) construction management, and (e) stadium operation. The influence of key stakeholder groups in these different project stages needs to be managed wisely when carrying out new development projects. The proposed framework discusses stakeholder influence and ways to manage it effectively. Managing stakeholder success perception through carefully designed project development stages helps project teams to be better prepared for this kind of real estate project.
\end{abstract}

Keywords - Construction management, project management, real estate, stadium development, stakeholder management.

\section{INTRODUCTION}

The 2014 FIFA world cup drew much attention to Brazil: The Brazilian hospitality, its open culture, but also the conditions under which soccer stadiums were built or renovated for this event. For some local building companies, projects had never been bigger and the operations were complex. Media reported that during the world cup preparation in Brazil the project management teams were constantly challenged due to the complexity of the development and construction process.

The development of stadiums and their construction are a complicated endeavor. Understanding the big picture and the process from initiation to completion is crucial to the successful implementation (Sartori \& Nienhoff, 2013). Of course, no major real estate project goes without any hiccups. However, literature reported that real estate project management often fails to consider the varying requirements. In particular, the influence of critical stakeholders on the development from the beginning is reported to be vital (Jingmin, Lechler \& Jun-long, 2010). Therefore, this paper contends that without a clear process and stakeholder understanding, stadium owners may be left with multiple problems during both development and construction but also when the facility ultimately becomes operational.

Although more than 120 stadiums have been constructed in the top European football leagues since 2000, a majority of European stadiums were built more than 35 years ago. They are often outdated and unable to meet market demands. Hence, major renovations or new stadium developments can be expected in the near future. The successful development or renovation of stadiums will be a pressing concern for key stakeholders such as the football clubs, municipality and other third parties who are involved in the ownership structure or the financing model.

\section{CHALlENGES IN STADIUM DEVELOPMENT}

During stadium development several issues may lead to pitfalls during project work and operation of the facilities: Think about not selecting the right site or not considering the local market. Think about building too large stadium with only the mega event of FIFA world cup in mind. Or think about not having considered sufficient hospitality and retail facilities affecting revenue opportunities. All these elements can determine the success of stadium development.

Given different kinds of large-scale real estate projects we commonly observe inferior portfolio and life-cycle decisions. Exactly these two features imply distinct questions around the adaptability for real estate use by third parties. In fact, we argue that real estate investment costs reflect only a fraction of the total costs along the entire life-cycle. The majority of lifecycle costs result from the actual real estate operation, such as maintenance (Bernhold et al., 2009; Bernhold, Nitzsche \& Rosenkranz, 2008). These costs, however, are already determined during the planning phase and are consequently influenced by user and stakeholder requirements.

Although real estate projects are always unique in nature, Sartori and Nienhoff (2013) point out that understanding the sequential steps and the need to understand the interdependencies between different phases are similar for the majority of projects. Moreover, Jing-min and his colleagues (Jing-min, Lechler \& Jun-long, 2010) argue that the role and influence of stakeholders during project phases determine the success of a major real estate project. We draw on this view and argue that along the different project stages the commitment and alignment of key stakeholders on commonly shared project goals are crucial for successful project management.

This article proposes a framework to effectively structure stakeholder effects along selected project phases within the stadium development context. With a constructivist understanding of success we follow Etzioni's (1960) goal model to effectively describe success dimensions during major real estate projects. These dimensions cover elements from the project initiation phase to project completion, including construction and stadium operation. Key stakeholders may vary from case to case and can be derived from these 
dimensions by project management. Based on previous real estate projects and the real estate literature, this conceptual paper proposes success dimensions that need to be considered for effective real estate development projects.

\section{SUCCESS OF PROJECT MANAGEMENT AS SOCIAL CONSTRUCTION}

Measuring and evaluating project management are reported as challenging objectives in the real estate literature (Jing-min, Lechler \& Jun-long, 2010; Pich, Loch \& De Meyer, 2002). Many stakeholders are involved in such events with different expectations, needs and perceptions. Researchers often apply generally available measures, including time line (and keeping it), budget (and staying within it), or architectural design (and implementing it) in trying to measure project activities objectively. Yet, costs of the actual real estate operation often neglect an integrated life-cycle perspective. A majority of real estate projects focus on keeping the budget of imposed investment costs only. However, this budget is commonly exceeded. Studies have shown that particularly in public building construction the budget is passed by almost $90 \%$ of the projects. Reasons for this vary, but commonly one key aspect is the late change of requirements that were agreed in the beginning (Bernhold, Nitzsche \& Rosenkranz, 2008). Therefore, we argue that requirement management from initiation to operation is needed that considers different stakeholder groups and potential consequences of life-cycle costs.

However, Jing-min and his colleagues (2010) criticized the variety of measurements and inconsistency in definitions that still do not provide a coherent perspective on the measurement of large-scale real estate projects. According to management scholars, a key reason for this might be the variety of characteristics important to develop success criteria to assess project management activities (Koners \& Goffin, 2007). Real estate development projects have shown that management activities and in particular the management of the projects itself determine the success of major real estate developments. In order to derive clear insights about interdependencies, a consistent understanding of project performance is needed.

Project performance can be described by two distinct models, namely the system model and the goal model (Etzioni, 1960). While the goal model evaluates the degree to which organizations are attaining defined goals, the system model additionally evaluates the project organization's abilities to acquire resources, to sustain system stability, as well as to interact with the environment effectively. Although the system model advances the success appraisal to a certain extent, practitioners highly value the goal model as it can be applied towards a concrete development project (Koners \& Goffin, 2007); Müller \& Turner, 2007). Consequently, we define project success as the degree to which the goals of a real estate development project are attained. Those goals might vary in key peoples' individual perception. While this is not an unusual effect, different or even contradictory objectives of key stakeholders within a real estate development project lead to challenging issues for project management.

\section{STAKEHOLDER MANAGEMENT IN LARGE-SCALE REAL ESTATE PROJECTS}

The involvement of different interest groups is something which can make large-scale real estate projects even more complex than they already are. Different stakeholders are involved throughout the development phases with different interests, opinions and expectations. In fact, "success means different things to different people" (Shenhar, Dvir, Levy \& Maltz, 2001) and stakeholder groups justify their opinion based on those perceptions. Therefore, it does not surprise that the success and performance of a real estate development project are perceived differently. As such, we argue that the real estate project can be considered successful when those different perspectives of all key stakeholders involved are taken into consideration thereby arriving at the same positive success judgment.

Understanding the success of a development project as social construction, we follow the common assumption that the appraisal of project management is based on the subjective perception of individuals or stakeholder groups within the project. This understanding relates back to Kelly's (1995) social constructivist theory and Festinger's (1954) theory of social comparison processes and has already been applied to change management theory (Greif, Runde \& Seeberg, 2004; Jacobs et al., 2004) and innovation theory (Goffin \& Koners, 2011; Lattuch et al., 2013). The authors found that performance figures need to be accepted and driven by key stakeholders within the project. Consequently, it is less important how project management defines goals and success officially and more important how stakeholders informally appraise activities at all levels of the project. In fact, stakeholders are more willing to support a project when perceiving it as successful and are less willing to support with a tendency of active or passive resistance for projects they perceive as failure. Hence, it can be stated that not only the enforcement of a development project is important, but also the satisfaction with it.

Stakeholder management needs to consider different views, interests and expectations during project work and to align the individual set of objectives. Management scholars (Burgelman, Christensen \& Wheelwright, 2009; Müller \& Turner, 2007) and management consulting (Lattuch \& Seifert, 2014; Mohe \& Seidl, 2011) offer a variety of concepts to consider key stakeholders in project developments. Their individual level of commitment and level of influence on the success of the project determine a better understanding of their role and importance during different project stages. As stated in the introduction, we consider the alignment of objectives during different project stages between key stakeholders as a predictor for a commonly shared success understanding and support for the project. Examples for these stakeholders are the governing body, financial sponsors, or football clubs and their supporters and fan base. 


\begin{tabular}{|c|c|c|c|c|c|}
\hline $\begin{array}{l}\text { Success } \\
\text { dimension }\end{array}$ & $\begin{array}{l}\text { Vision and } \\
\text { Expectation }\end{array}$ & $\begin{array}{l}\text { Risk and } \\
\text { feasibility }\end{array}$ & $\begin{array}{l}\text { Project planning } \\
\text { and design }\end{array}$ & $\begin{array}{l}\text { Construction } \\
\text { management }\end{array}$ & $\begin{array}{l}\text { Stadium } \\
\text { operation }\end{array}$ \\
\hline & $\downarrow$ & $\nabla$ & $\downarrow$ & $\downarrow$ & $\downarrow$ \\
\hline Challenge & $\begin{array}{l}\text { - Vision unclear } \\
\text { - Divergent } \\
\text { expectations }\end{array}$ & $\begin{array}{l}\text { - Analysis of location, } \\
\text { market, stadium } \\
\text { concept, operational } \\
\text { forecast / financials }\end{array}$ & $\begin{array}{l}\text { - Not all stakeholder } \\
\text { groups are typically } \\
\text { involved in planning }\end{array}$ & $\begin{array}{l}\text { - Complex party } \\
\text { involvement with } \\
\text { high risk cost, } \\
\text { schedule and quality }\end{array}$ & $\begin{array}{l}\text { - Commercial } \\
\text { business model } \\
\text { meets stadium } \\
\text { vision / expectation }\end{array}$ \\
\hline $\begin{array}{l}\text { Initial key } \\
\text { questions }\end{array}$ & $\begin{array}{l}\text { "What do we want?" } \\
\text { "What do we really need?" } \\
\text { "What can we afford?" }\end{array}$ & $\begin{array}{l}\text { "Are risks assessed?" } \\
\text { "Is feasibility secured?" } \\
\text { "Are parties committed?" }\end{array}$ & $\begin{array}{l}\text { "Are all parties involved?" } \\
\text { "Are critical parties } \\
\text { mapped and managed?" }\end{array}$ & $\begin{array}{l}\text { "Are implementation risks } \\
\text { allocated effectively?" } \\
\text { "Do contracts cover cost, } \\
\text { schedule / quality issues?" }\end{array}$ & $\begin{array}{l}\text { "Is business model } \\
\text { successfully } \\
\text { assessed during } \\
\text { design phase?" }\end{array}$ \\
\hline
\end{tabular}

Stakeholder groups

Actions for
project
performance

Football club, municipality, fan base, sponsors, media, public authorities, financing institutions, constructor, architects, urban planner, engineer, contractor, operator, UEFA, FIFA, etc.

\begin{abstract}
(1) Ensure overall and phase specific goal alignment between key stakeholders
(2) Map and analyze stakeholder groups with regards to their attitude and influence / impact on the project performance

(3) Evaluate stakeholders' success appraisal and adjust group specific objectives
\end{abstract}

Fig. 1. Five success dimensions in stadium development projects and relations to effective stakeholder management.
The following framework describes critical project stages and involved stakeholder groups in stadium development. Based on their individual interests, considerations are proposed to align the varying interests into a commonly shared goal and success understanding. As illustrated in Fig. 1, these dimensions cover the project vision and expectation, a risk and feasibility analysis, project planning and design, construction management and stadium operation.

\section{FRAMEWORK DIMENSIONS AND THEIR INTERDEPENDENCIES IN STADIUM DEVELOPMENT}

Stadium development is not only managed through different project stages, it also concerns different stakeholder groups in each phase that need to be considered for successful project management. Since these groups may have a different perspective on the project, scholars recommend illustrating and organizing them in stakeholder maps (Jing-min, Lechler \& Jun-long, 2010). These mappings may vary from case to case but generally position different stakeholders with regard to their attitude towards the project and their influence and impact on the project performance. The following typical interest groups with influence on the project success are critically decried for five critical success dimensions during stadium development, namely (a) vision and expectation, (b) risk and feasibility, (c) project planning and design, (d) construction management, and (e) stadium operation.

\section{A. Project Vision and Expectation}

Although Sartori and Nienhoff (2013) stated that a project vision is typically initiated by one party such as a football club or a public institution, recent stadium developments have shown that typically more than one party is involved. As such these parties may have different, sometimes contradicting positions. For example, if a club is named by a sponsor whose brand will also be an element of the new stadium name, it is quite likely that the sponsor as a finance institution may also participate in vision discussions. The owner structure between publicly-owned and privately-owned facilities can also create interest group combinations that vary from case to case.

Due to different reasons for developing a new stadium or renovating an existing one, the vision and expectation need to be aligned by all key stakeholders. According to the UEFA (2011), such alignment needs to cover the three main questions of (a) what do we want, (b) what do we really need, and (c) what can we afford. In fact, having an agreement at the initial project stage in terms of a vision that is doable and realistic can help to frame expectations of subsequent considerations. This vision can be defined and challenged by the stakeholders during vision workshops on the basis of market requirements and the actual budget to implement the planning. Fan surveys can also help in shaping the vision. In doing this exercise a commonly aligned vision can be approved that considers project expectations and different interest groups at the same time.

As part of the project initiation it also needs to be considered whether the site usage is reversible or adaptable to third parties. Compared to other real estate projects, the development of sport arenas has a distinct specificity. Moreover, the requirements for usage along the life-cycle and its potential change over time may be addressed.

\section{B. Risk and Feasibility Analysis}

In order to successfully develop and transfer the project into the design, construction and operation stages a risk and feasibility analysis is crucial and results need to be shared with key stakeholders. The analysis covers issues on the location, market, stadium concept, operational forecast and financials. Moreover, it also needs to integrate macroeconomic and technological conditions. Each location is unique in nature and its characteristics in terms of ownership, land size, typography 
and environment may vary. An assessment including these features helps to better understand the opportunities and weaknesses of the potential site. From a market perspective, the potential demand for the stadium's core and multi-usage, existing competition and further commercialization potential need to be addressed. This includes the actual urban catchment, market value as well as competition and pricing analysis. In alignment with location and market, the stadium concept is then analyzed on the basis of site opportunities and capital constraints. Apart from others, Sartori and Nienhoff (2013) argued that testing the concept with future operating and financial performance elements can lead to refinements that ultimately result in a robust concept that is likely to hold in practice. Elements such as the stadium capacity, product and service mix as well as the capital expenditures may be adjusted to these refinements accordingly. With the market and concept assessment, the operating performance can be analyzed with focus on operation risks, sustainability and financial feasibility. Prospected operating revenues and expected operating costs provide important input in this assessment stage. Having identified different drivers within the revenue and cost perspective, the profitability can be analyzed through sensitivity analysis leading to the operating cash flow for the upcoming years. According to Jing-min and his colleagues (Jing-min, Lechler \& Jun-long, 2010), the arrangement of financing structures for stadium development is a challenging task. However, such assessment helps to assess the financial performance of the project, the ability to source funding and to meet expectations of capital providers.

Numerous documents including technical studies and surveys help to conduct a risk and feasibility analysis. From a stakeholder perspective, the involvement of public authorities and other stakeholders engaged in land ownership is important for location issues. For the market context the supporter base is a major source of analysis. Fan surveys, focus groups and interviews with key supporters help to better understand their needs and behavioral patterns. Different approaches can be tested by evaluating supporter reactions to facility issues or new product concepts. During the concept stage stakeholders including finance institutions, public authorities, the football club itself or other capital providers play a critical role in challenging the concept in terms of feasibility and financial robustness. The ability to source funding is important to capital providers. In recent years researchers have observed that along financial stakeholders securitization though preselling parts of future revenues is a common way to reduce risks for financial investors. Clearly, a robust business plan by the stadium owner and operator is the foundation for successful negotiations with investors. As such it can demonstrate that expectations of all capital providers can be met.

For the risk and feasibility analysis, the inclusion and participation of specific stakeholder groups are vital during the different assessment stages. While public authorities' opinion and assessment of the project are important during the location analysis, the inclusion of fan surveys is a key factor to determine the pricing and demand level. Findings help to refine the concept in order to satisfy stakeholders who provide financial support such as public authorities, financing institutions and other parties. Key stakeholders also need to be aware of assumptions made to carry out the feasibility analysis. Once the feasibility assessment is completed, result workshops with selected stakeholders can help to align an integrated view on the project and its overall objectives.

\section{Project Planning and Design}

Stadium development projects vary according to the location, site, market conditions and stakeholders needs. Therefore, project managers tailor the planning and design process accordingly (Pich, Loch \& De Meyer, 2002). During the preparation phase stakeholders are involved in cost estimations and regulatory subjects, including permitting issues. Other stakeholder groups may be involved in the concept design creating identity and stadium character development. After project management initially clarifies these features, it then structures the development design with architectural and site concepts as well as the technical design with construction plans and handover actions to tender and constructors.

The highlighted phases involve different stakeholder groups at different points in time. While stakeholders are typically involved in the phase where their professional involvement and input are needed, we have experienced that shifting this involvement to earlier stages can help to identify pitfalls and risk before they actually occur. Within this context, it can be assumed that the involvement of pragmatic technicians and constructors at an earlier creative concept design stage can reduce the quantity of creative ideas. However, management scholars have found that early involvement of pragmatic stakeholders at creative design stages can help to focus on ideas that are feasible and realistic. Ratcliffe and his colleagues (2005) made similar observations in real estate developments. Hence, it can be contended to involve key stakeholders from the technical design phase such as architects, engineers or constructors also in earlier phases such as concept and development design.

Shifting critical stakeholders from their traditional project phases to earlier involvement can help to enrich their picture of the project, its challenges and opportunities. Having the big project picture in mind can also influence their individual perception of different project assumptions, objectives and the degree to which they can be realistically achieved. According to Pich and his colleagues (2002), this involvement needs to be managed wisely by project management in order to avoid progress disruptions. In fact, this flexible stakeholder involvement can help to arrive at a commonly shared understanding of project progress, feasibility and likelihood of goal achievement.

In this context, a major part of the operating costs within the design of real estate projects is determined and partly irreversibly fixed by the choice of elements such as technical components or room functionalities (Pelzeter, 2006). As a consequence, the consideration of integrative planning of real estate projects across life-cycle phases as well as the 
homogenous consolidation of products and services becomes more and more important.

Construction costs are no longer the data that determine the consideration of the initial investment. It is rather represented by the total costs of all life-cycle phases. Therefore, the exchange of relevant information between all participating actors is vital to understand the entire cost structure. For instance, Bernhold et al. (2009) stated that a regulatory framework might represent a solid foundation of information exchange during a real estate project.

Resulting from the discussion above, the following requirements arise for management within such a real estate life-cycle (Bernhold et al., 2009; Bernhold, Nitzsche \& Rosenkranz, 2008):

1. Interface management in the context of cooperation- and network building to differentiate precisely between tasks, responsibilities and liability issues.

2. Design of a company-wide development process for hybrid products and analysis of the overall network of relations with regard to partial contributions.

3. Implementation of a professional requirement management system.

4. Design of the information flow between different services/benefits to ensure an error-free process as well as interaction to attune and integrate the further process of development.

5. Implementation of a numeric calculation model to reliably estimate the economic efficiency by determining interdependencies of materials and components from lifecycle costs.

6. Implementation of a risk management system, e.g., in the case of liability issues and/or warranty/guarantee questions/issues.

7. Access to all relevant and up-to-date real estate information and data within the life-cycle.

8. Implementation of an expert knowledge pool to integrate relevant aspects of the real estate life-cycle (e.g., norms, directives and ratios).

\section{Construction Management}

Construction management is often as complex as the entire administrative project development itself (Jing-min, Lechler \& Jun-long, 2010). Different stakeholder groups are involved during infrastructure construction, foundation work, organizing concrete and prefabricated elements, mechanical, electrical and plumbing installations, roof construction and facade work, as well as furnishings, fixtures and equipment organization. Football clubs and their project managers who are experienced in major real estate projects are reported as being more aware of the risks associate with construction and better understand associated implications (Davis, 2006). These risks mainly cover cost, schedule and quality. Based on these major risks and their interdependencies within construction management, project management can identify critical stakeholders and their experience.

Different contracting strategies are available to project management during the construction phase. While risks can be allocated to stakeholders on the construction side for a design and build approach, however, risks remain with regard to stakeholders involved in ownership. Researchers have also discussed a traditional approach that balances the risks between the constructor and building owner (Atherton, French \& Gabrielli, 2008; Ratcliffe, Stubbs \& Shepherd, 2005). All these different approaches shift responsibilities and associated risks to different stakeholder groups. If not managed actively risks of poor quality design and late changes can lead to significant delay, disruption and claims. If project managers are not aware of these risk shifts, they may find it difficult to manage these groups effectively during the construction phase.

If many stakeholders have a significant influence on the construction management, Sartori and Nienhoff (2013) suggest that the project manager may pass implementation risks to the constructor. In fact, this offers a single point of responsibility for the project, but also implies less control over quality once the contract is in place (UEFA, 2011). To manage involved stakeholders successfully, contracts need to state quality standards and specify any adjustments to the scope of work. The specifications of these contracts are important as the spirit under which such contracts are signed is typically not the same spirit when the agreements are put into operation during the construction phase. Evaluation workshops with key stakeholder groups at the beginning and during the construction phases help to better understand developments, challenges and agreements that are made in order to mitigate construction risks.

\section{E. Stadium Operation}

Stadium operation and its management are the final phases in the proposed stadium development approach. In stadium management, the commercial business model is the basis for successful implementation of the operation plans. The ownership structure and financing model provide the first indicators of critical stakeholders in this phase. Make or buy decisions determine the risk level for stadium owners such as football clubs, municipality or other third parties (UEFA, 2011). Ambiguity on the commercial business model may impact financial stakeholders and their decision-making during early project development stages.

Sartori and Nienhoff (2013) report different stadium operation models. From a risk perspective, project stakeholders take over low risks when the stadium is operated through lease agreements. In turn, operating the stadium by the owner implies a high risk for the project stakeholders but also leaves the complete control of the assets and potential upside from exceeding expected operating results to the owner. The decision to appoint external stadium management through lease or management agreements is not only beneficial from a risk perspective. Early involvement of this external stakeholder party in the development project can enable him to influence the design phase in order to align the commercial business model with site characteristics. Hence, operator's considerations can support the development in terms of efficiency and revenue generation opportunities. 
Researchers state that the decision of who will operate the stadium needs to be addressed in an early project development stage (Davis, 2006; Sartori \& Nienhoff, 2013). Leaving such a decision until a late stage after the stadium is built can result in uncertainty for stakeholders who may take associated risks. Therefore, in order to manage stakeholders effectively during the stadium operation phase project management needs to address the stadium management model at an early project stage.

\section{CONCLUSION}

The article described that stadium developments strike different stakeholder groups from project initiation to completion. These groups can have different perspectives and individual objectives in the project and may share different success notions. With the underlying constructivist understanding of success and following Etzioni's (1960) goal model the stakeholder specific objectives need to be managed along success dimensions for an effective project performance.

Stakeholder analysis and consequent mappings consider different stakeholder groups and their impact on the project. These mappings generally position different stakeholder groups with regard to their attitude toward the project and their influence and impact on the project performance. The need to manage different interest groups with influence on the project success is highlighted by five critical success dimensions during stadium development (Fig. 1).

Despite the discussed success dimensions, the real estate managers also need to keep stadium specific risks in mind that also factor into the overall assessment (Bulan, Mayer \& Sommerville, 2009). For instance, Sartori and Nienhoff (2013) point out that sport specific risks may also impact the success of the new stadium development. The two researchers highlighted (1) unpredictability of team's performance and sport success, (2) retention of new target markets, (3) financial stability of the investors, (4) violent behavior of club supporters, and (5) unexpected increase of competition. Real estate researchers, therefore, argue that a comprehensive business plan considers and evaluates these risks. Developing different scenarios can help project management consider different mitigation actions ahead of critical project stages.

Based on the description of success dimensions, further considerations for stadium development projects can also be derived from this discussion:

- Be aware of different interest groups, their expectations and objectives they have regarding the project development. Align these objectives into a common understanding during different project stages.

- Maintain flexibility in stadium concept during development stages with regard to success dimensions since findings on site, market and financial issues will impact the size, quality and cost of the stadium.

- Involve affected stakeholder groups and allow them to participate in selected development phases where their input is relevant and valuable.
- Shift key stakeholders to earlier development stages. When incorporated effectively, their input can help to avoid upcoming pitfalls or hiccups in construction and operation phases.

- Involve the fan base as an important stakeholder group during development and operation to avoid future disputes and negative public relations.

- Pass project implementation risks to the constructor where necessary and specify expected quality levels in contract negotiations.

- Address the stadium management model at an early stage during the development project in order to better manage affected stakeholders and offer involvement of external management companies during these phases, if necessary.

- Measure progress regularly but minimize the scope adjustments by committing to realistic objectives.

The management of the overall and partial project objectives, risks and mitigations has been found to be critical for stakeholder management. Mapping of critical stakeholder groups with regard to their attitude towards the project and their influence and impact on project performance can help to better anticipate and plan project management activities along the six success dimensions. Regular evaluations can support stakeholder alignment and enable effective project adjustments, increased stakeholder involvement and project performance.

\section{REFERENCES}

Atherton, E. A., French, N. \& Gabrielli, L. (2008). Decision theory and real estate development: a note on uncertainty. Journal of European Real Estate Research, 1, pp. 162-182. http://dx.doi.org/10.1108/17539260810918730

Bernhold, T., Dircksen, M., Haastert, M., Keeve, H., Lönnegren, H.-M., Melchert, M., Rosenkranz, C. \& Schäfermeyer, M. (2009). Management der Integration von Dienstleistungen und Produktion im Baugewerbe, Endbericht zum Forschungsprojekt Mind-Bau, Münster, Ahlen, Frankfurt am Main.

Bernhold, T., Nitzsche, F. \& Rosenkranz, C. (2008). Ein Ordnungsrahmen für lebenszyklusorientierte Planung im Facility Management. In Bichler, M., Hess, T., Krcmar, H., Lechner, U., Matthes, F., Picot, A., Speitkamp, B. \& Wolf, P. (Eds.) Multikonferenz Wirtschaftsinformatik 2008. Berlin, GitoVerlag.

Bulan, L., Mayer, C. \& Sommerville, C. T. (2009). Irreversible investment, real options, and competition: evidence from real estate development. Journal of Urban Economics, 65, pp. 237-251. http://dx.doi.org/10.1016/j.jue.2008.03.003

Burgelman, R. A., Christensen, C. M. \& Wheelwright, S. C. (2009). Strategic management of technology and innovation, New York, McGraw-Hill.

Davis, L. E. (2006). Sporting a new role? Stadia and the real estate market. Managing Leisure, 11, pp. 231-244. http://dx.doi.org/10.1080/13606710600893726

Etzioni, A. (1960). Two approaches to organizational analysis: A critique and a suggestion. Administrative Science Quarterly, 5, pp. 257-278. http://dx.doi.org/10.2307/2390780

Festinger, L. (1954). A theory of social comparison processes. Human Relations, 7, pp. 117-140. http://dx.doi.org/10.1177/001872675400700202

Goffin, K. \& Koners, U. (2011). Tacit knowledge, lessons learnt, and new product development. Journal of Product Innovation Management, 28, pp. 300-318. http://dx.doi.org/10.1111/j.1540-5885.2010.00798.x

Greif, S., Runde, B. \& Seeberg, I. (2004). Erfolge und Misserfolge beim Change Management, Göttingen, Hogrefe.

Jacobs, G., Keegan, A., Christe-Zeyse, J., Seeberg, I. \& Runde, B. (2006) The fatal smirk: insider accounts of organizational change processes in a police organization. Journal of Organizational Change Management, 18, pp. 173-192. http://dx.doi.org/10.1108/09534810610648898 
Jing-min, N., Lechler, T. G. \& Jun-long, J. (2010). Success criteria framework for real estate project. Management Science and Engineering, 4, pp. 10-23.

Kelly, G. A. (1955). A theory of personality: the psychology of personal constructs, New York, Norton.

Koners, U. \& Goffin, K. (2007). Learning from postproject reviews: a crosscase analysis. Journal of Product Innovation Management, 24, pp. 242-258. http://dx.doi.org/10.1111/j.1540-5885.2007.00248.x

Lattuch, F., Pech, R. J., Riemenschneider, F. \& Weigert, M. (2013). Market and technology drivers: shaping an innovation strategy. Journal of Business Strategy, 34, pp. 4-11. http://dx.doi.org/10.1108/JBS-05-2013-0034

Lattuch, F. \& Seifert, A. (2014). Insights from change management consulting: Linking the hard and soft side of change with heuristics. In Albach, H., Mefert, H., Pinkwart, A. \& Reichwald, R. (Eds.) Management of permanent change. Springer.

Mohe, M. \& Seidl, D. (2011). Theorizing the client - consultant relationship from the perspective of social-systems theory. Organization, 18, pp. 3-22. http://dx.doi.org/10.1177/1350508409353834

Müller, R. \& Turner, R. (2007). The influence of project managers on project success criteria and project success by type of project. European Management Journal, 25, pp. 298-309. http://dx.doi.org/10.1016/j.emj.2007.06.003

Pelzeter, A. (2006). Lebenszykluskosten von Immobilien. Einfluss von Lage, Gestaltung und Umwelt. ebs Department of Real Estate Stiftungslehrstuhl Immobilienökonomie. Oestrich-Winkel, European Business School - International University Schloß Reichartshausen.

Pich, M. T., Loch, C. H. \& De Meyer, A. (2002). On uncertainty, ambiguity and complexity in project management. Management Science, 48 , pp. 1008-1023. http://dx.doi.org/10.1287/mnsc.48.8.1008.163

Ratcliffe, J., Stubbs, M. \& Shepherd, M. (2005). Urban planning and real estate development, New York, Taylor Francis.

Sartori, A. \& Nienhoff, H. (2013). A blueprint for successful stadium development. KPMG Sports Advisory, www.kpmg.com (accessed at May 2014).

Shenhar, A. J., Dvir, D., Levy, O. \& Maltz, A. C. (2001). Project success: a multidimensional strategic concept. Long Range Planning, 34, pp. 699-725. http://dx.doi.org/10.1016/S0024-6301(01)00097-8

UEFA (2011). UEFA guide to quality stadiums. Union of European Football Associations, www.uefa.com (accessed 1 June 2014).

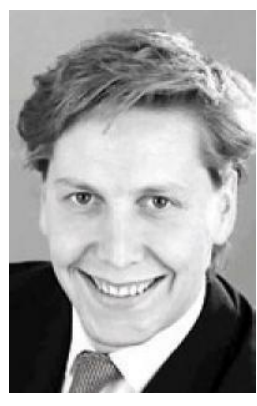

Dr. Torben Bernhold is a Professor of Facility Management at the Muenster University of Applied Sciences. He is also a managing partner at the Institute of Site und Facility Management (ISFM $\mathrm{GmbH})$ in Germany.

E-mail: bernhold@fh-muenster.de

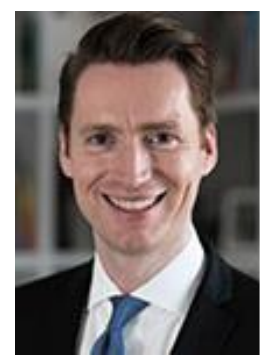

Dr. Frank Lattuch is a Senior Consultant at KPMG's Strategy and Operations practice with focus on transformation management and business innovation. He advises on multinational clients in Europe, Asia and the US.

E-mail: FLattuch@kpmg.com

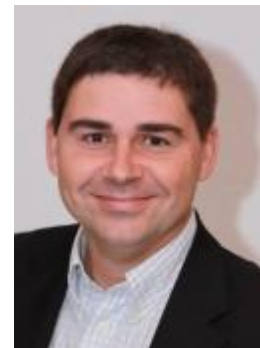

Dr. Frank Riemenschneider is a Professor of Management at the Muenster University of Applied Sciences. He consults and researches in the field of innovation, service engineering and facility management.

E-mail: riemenschneider@fh-muenster.de 